JPdK Volume 3 Nomor 2 Tahun 2021 Halaman 20-29

JURNAL PENDIDIKAN dan KONSELING

Research \& Learning in Primary Education

\title{
Keikutsertaan Pendidikan Kewarganegaraan dalam Upaya Membangun Karakter Berbangsa dan Bernegara Indonesia
}

\author{
Hasna Salsabila ${ }^{1}$, Dinie Anggraeni Dewi ${ }^{2}$ \\ Program Studi Pendidikan Guru Sekolah Dasar \\ Fakultas Keguruan dan Ilmu Pendidikan \\ Universitas Pendidikan Indonesia \\ Email: hasnasalsabila2@upi.edu ${ }^{1}$, dinieanggraenidewi@upi.edu ${ }^{2}$
}

\begin{abstract}
Abstrak
Kondisi warga negara Indonesia saat ini dapat dikatakan kurang baik dalam hal karakter berbangsa dan bernegara. Hal ini dapat terjadi karena masuknya teknologi yang tidak terkontrol. Masyarakat Indonesia tidak bisa memilah mana saja yang dapat memberikan dampak positif terhadap kehidupan berbangsa dan bernegara. Dapat dilihat pula bahwa budaya Korupsi, Kolusi dan Nepotisme sangat marak terjadi. Selain itu, masyarakat Indonesia pun sering kali mudah terpacu konflik karena intoleran. Oleh karena itu, keikutsertaan Pendidikan Kewarganegaraan dalam membangun karakter berbangsa dan bernegara diharapkan dapat memperbaiki karakter dari masyarakat Indonesia.
\end{abstract}

Kata Kunci : Pendidikan, Pendidikan Kewarganegaraan, Karakter Berbangsa dan Bernegara

\begin{abstract}
The current condition of Indonesian citizens can be said to be unfavorable in terms of national and state character. This can happen because of uncontrolled entry of technology. The Indonesian people cannot sort out which ones can have a positive impact on the life of the nation and state. It can also be seen that the culture of Corruption, Collusion and Nepotism is rampant. In addition, Indonesian society is often prone to conflict because of intolerance. Therefore, the participation of Citizenship Education in building the character of the nation and state is expected to improve the character of Indonesian society.
\end{abstract}

Keywords : Education, Citizenship Education, Character of The Nation and State.

Orde Baru, dan Reformasi.

\section{PENDAHULUAN}

Negara Indonesia mengalami masa penjajahan selama kurang lebih 350 oleh negara Belanda. Setelah masa penjajahan, Bangsa Indonesia pun harus melewati masa perjuanagn melawan penjajah, masa perjuangan menegakkan kemerdekaan, dan masa perjuangan mengisi kemerdekaan atau sering kita dengar masa Orde Lama,
Perjuangan rakyat Indonesia pada masingmasing masa tentunya berbeda-beda. Pada masa penjajahan, rakyat Indoensia harus mampu berjuang untuk dapat bertahan dengan kondisi negara yang kacau karena sumber daya alam dan sumber daya manusia diekspolitasi oleh para penjajah. Selanjutnya pada masa perjuangan melawan penjajah, rakyat Indonesia harus berjuang mengerahkan seluruh kemampuannya, rela berksorban untuk mendapatkan kemerdekaan yang hakiki. 
Kemudian pada masa mengisi kemerdekaan rakyat Indonesia harus kembali berjuang untuk dapat mengisi kemerdekaan Indonesia, contohnya seperti melalui pendidikan yang dimaksudkan untuk mencerdaskan kehidupan bangsa.

Dilihat dari perjalanan bangsa Indonesia, maka Bangsa Indonesia perlu generasi penerus untuk dapat melanjutkan kehidupan bangsa serta mempertahankan kemerdekaan bangsanya. Tantangan bagi generasi muda Indonesia saat ini mungkin bukan berupa penjajahan fisik seperti penjajahan, namun perang pemikiran dan karakter. Hal ini dapat terjadi karena kemajuan teknologi yang amat pesat.

Era Revolusi Industri 4.0 ditandai dengan munculnya berbagai inovasiinovasi teknologi. Contohnya dengan adanya aplikasi-aplikasi yang memberikan kemudahan dalam aktivitas sehari-hari, seperti shopee, lazada, tokopedia, gojek, grab, dan masih banyak lagi. Aplikasiaplikasi ini memang memudahkan dalam kehidupan sehari-hari. Namun, di samping itu juga terdapat dampak negatif dari adanya aplikasi-aplikasi tersebut. Karena aplikasi tersebut bersifat online, maka interakasi sosial menjadi semakin berkurang. Masyarakat Indonesia juga akan menjadi lebih individualistis. Jika dibiarkan, hal ini dapat menyebabkaan berkurangnya kepekaan sosial antar masyarakat. Kemajuan teknologi juga berbarengan dengan kemajuan komunikasi dan informasi. Banyak informasi dari luar yang dengan sangat mudah masuk ke Indonesia. Tanpa terkecuali hal-hal atau budaya tidak baik dari luar masuk ke Indonesia. Hal ini dapat menyebabkan lunturnya karakter-karakter dan budaya serta jiwa nasionalisme masyarakat Indonesia.
Jika dilihat dari perjalanan bangsa Indonesia, maka tidak terlepas dari peran generasi muda. Generasi muda memiliki peran yang besar dalam mencapai tujuan dan kemerdekaan bangsa Indonesia. Generasi muda, tepatnya mahasiswa, berperan sebagai agent of change. Artinya, mahasiswa berperan dalam perubahanperubahan bangsa Indonesia untuk menjadi bangsa yang lebih baik. Maka dari itu, agar tidak kembali pada masa penjajahan, bangsa Indonesia melakukan upaya perbuahan, salah satunya dengan adanya pemelajaran Pendidikan Kewarganegaraan. Pendidikan Kewarganegaraan ini diharapkan dapat membangun karakter dan kesadaran bernegara.

\section{METODOLOGI PENELITIAN}

Metode yang digunakan dalam pembuatan artikel ini adalah metode studi literatur. Menurut Zed (2008:1) riset pustaka memanfaatkan sumber perpustakaan untuk mempearoleh data penelitian, riset kepustakaan berkenaan dengan metode pengumpulan data pustaka, membaca dan mencatat serta mengolah bahan penelitian.

Metode studi literatur ini hanya memanfaakan sumber-sumber pustaka sebagai bahan untuk memperoleh suatu hasil penelitian. Sumber yang digunakan dalam penulisan artikel ini dapat bersumber dari buku-buku, jurnal ilmiah, artikel, esai, dan sebagainya. Dalam artikel yang saya buat ini, literatur yang digunakan berkenaan dengan Pendidikan Kewarganegaraan dan Karakter Bangsa. Teknik pengumpulan data dilakukan dengan mengumpulkan berbagai literatur yang tentunya berkaitan dengan judul artikel ini. Sedangkan teknik analisis data dilakukan denan mengumpulkan literatur 
atau bahan yang diperoleh, membacanya, kemudian disusun serta dikaitkan antara satu dengan yang lainnya sehingga akan mendapatkan hasil atau kesimpulan.

Undang-Undang No. 20 Tahun 2003 tentang sistem pendidikan Nasional menyatakan bahwa setiap jenis, jalur dan jenjang pendidikan wajib memuat pelajaran yang terdiri dari Pendidikan Bahasa, Pendidikan Agama, dan Pendidikan Kewarganegaraan. Hal ini menunjukan bahwa Pendidikan Kewarganegaraan berperan penting dalam pembentukan karakter pribadi generasi muda serta membangun kesadaran sosial.

Peran PKn bagi berjalannya hidup berbangsa dan bernegara sangatlah strategis. Pkn sendiri bertujuan untuk mempersiapkan generasi atau peserta didik untuk menjadi warga negara yang baik (to be good and smart citizens) dimana memiliki komitmen yang kuat dalam mempertahankan kebhinekaan di Indonesia dan mempertahankan interitas nasional. Menurut Budimansyah \& Suryadi (Kariadi, 2017: 31) "PKn merupakan salah satu bidang kajian yang mengemban misi nasional untuk mencerdaskan kehidupan bangsa". Maka di dalam kurikulum PKn terdapat materi yang diharapkan dapat memberikan pemahaman kepada mahasiswa mengenai informasi mengenai kewarganegaraan.

Pendidikan Kewarganegaraan diberikan kepada peserta didik supaya dapat menjadikan mereka warga Negara yang baik. Bagaimanakah pendidikan kewarganegaraan berperan dalam pembangunan dan pengembangan karakter dalam diri generasi muda, tentu dapat terjawab jika kontribusi yang diberikan pendidikan kewarganegaraan berhasil mengarahkan generasi muda saat ini untuk berpartisipasi mengusung karakter bangsa (Kaelan, 2010).

\section{A. Pendidikan Kewarganegaraan Untuk Masyarakat}

Pendidikan Kewarganegaraan untuk masyarakat memiliki tujuan agar masyarakat Indonesia dapat mengetahui, mengerti, memahami, serta mengimplementasikan nilai-nilai atau tata tertib yang sesuai dengan kaidah hukum yang berlaku dimasyarakat yang di mana terdapat dalam Pendidikan Kewarganegaraan.

Namun pendidkan kewarganegaraan untuk masyarakat ini dirasa masih belum adil. Sebagai contoh, apabila seorang warganegara bekerja sebagai pegawai negeri sipil, ABRI/POLRI, anggota legislatif, mereka selalu mendapatkan Pendidikan Kewarganegaraan dalam kegiatan pekerjaannya, sementara warge nagara yang bekerja sebagai supir bus, pedagang kaki lima, tukang becak, mereka tidak mendapatkan Pendidikan Kewarganegaraan.

\section{B. Pendidikan Kewarganegaraan Untuk Sekolah}

Pendidikan Kewarganegaraan untuk sekolah yakni pendidikan kkewarganegaraan yang wajib dilakukan dilembaga-lembaga sekolah baik sekolah swasta maupun negeri, mulai dari jenjang sekolah rendah hingga perguruan tinggi. Sebagaimana yang telah diamanatkan dalam Undang-Undang sistem pendidikan nasional (UU No. 20 tahun 2003) yang menekankan bahwwa kurikulum sekolah haruslah memuat pendidikan agama, Bahasa Indonesia dan Pendidikan Kewarganegaraan. 
Maka dari itu, pemerintah melalui Departemen Pendidikan Nasional beserta jajarannya telah membuat pedoman penulisan kurikulum tingkat satuan pendidikan melalui Permen No. 22, 23, dan 24 Tahun 2006 tentang standari isi, standar kompetensi lulusan dan pedoman pelaksanaan Kurikulum Tingkat Satuan Pendidika. Sehingga, seperti yang kita ketahui sekarang bahwa Pendidikan Kewarganegaraan untuk sekolah telah berjalan. Namun di samping itu tetap masih ada beberapa kekurangan dalam pelaksanaanya. Tidak sedikit dari siswa menganggap PKn ini sebagai pelajaran yang tidak begitu pending. Mereka menganggap PKn hanya sebatas menghapal materi. Sehingga fungsi PKn sebagai pendidikan karakter ini kurang terlaksana secara maksimal. Hal ini berkaitan dengan bagaimana tahap perencanaan pebelajaran atau kita mengenalnya dengan istilah Rencana Pelaksanaan Pendidikan (RPP). RPP memiliki fungsi yang penting dalam mewujudkan Pendidkan Kewarganegaraan yang dapat menjadi pendidikan yang membangun karakter berbangsa dan bernegara.

\section{Karakter Berbangsa dan Bernegara}

Apabila kita melihat pada fakta saat sekarang ini masyarakat Indeonsia dapat dikatakan krisis karakter. Secara karakter pribadi, banyak dari warga Indonesia yang sangat individualisme, mementingkan diri sendiri, keluarganya, atau kelompoknya masing-masing. Selain itu kita bisa lihat maraknya kasus $\mathrm{KKN}$
(Korupsi, Kolusi, dan Nepotisme, hal ini menandakan sikap masyarakat Indoensia yang tidak jujur dan tidak profesional. Di samping itu, secara karakter Kebangsaan, masyarakat Indonesia juga dapat dikatakan belum memiliki karakter kebangsaan Indonesia. Contohnya banyak terjadi tawuran antar suku, antar desa, atau antar sekolah. Kita seakan melupakan nilai-nilai luhur bangsa Indonesia, yang antara lain adalah patriotsme, nasionalisme, toleransi, kekeluargaan, saling menghormati. Kita seakan lupa semboyan negara, Bhineka Tunggal Ika yang berarti berbeda-neda tetapi tetap satu. Hal ini menjadi salah satu alasan pentingnya Pendidikan Pancasila untuk membangun karakter berbangsa dan bernegara.

\section{HASIL PENELITIAN DAN PEMBAHASAN}

\section{A. Pendidikan Kewarganegaraan}

Kewarganegaraan dalam bahas latin disebut civis, selanjutnya dari kata civis dalam bahasa Inggris timbul kata civic, artinya mengenai warga negara atau kewarganegaraan. Kemudian dari kata civic muncullah kata civics yang berarti ilmu kewarganegaraan dan civic education yang berarti pendidikan kewarganegaraan.

Menurut Zamroni, Pendidikan kewarganegaraan adalah pendidikan demokrasi yang bertujuan untuk mempersiapkan warga masyarakat berpikir kritis dan bertindak demokratis. Pembelajaran merupakan bagian atau elemen yang memiliki peran yang sangat dominan untuk 
mewujudkan kualitas baik proses maupun lulusan (output) pendidikan, hal ini pun sangat tergantung pada proses belajar mengajarnya (Kaelan, 2010).

Maka dari itu kita dapat mengetahui bahwa Penddikan Kewarganegaraan ini sangat penting. Sebagai materi pembelajaran, Pendidikan Kewarganegaraan memiliki tujuan yaitu membantu peserta didik menjadi warga negara yang dapat memahami esensi dari karakter warga negara Indonesia yang menjunjung tinggi toleransi, kebudayaan, dan nasinalisme. Hubungan Pendidikan Kewarganegaraan dengan pengembangan karakter ini sangat berkaitan dengan aspek pembentukan karakter dan moralitas warga negara.

Selanjutnya, Pendidikan

Kewarganegaraan ini merupakan hal yang mendasar, yang dapat membawa masyarakat untuk dapat mengetahui berbagai macam hal yang berkaitan dengan kemasyarakatan dan kenegaraan.

Prinsip dasar dari Pendidikan Kewarganegaraan yakni suatu upaya sadar dan terencana untuk mencapai tujuan nasional bangsa, yakni mencerdaskan kehidupan bangsa. Mencerdaskan kehidupan bangsa dapat dilakukan melalui penumbuhan jati diri dan moral bangsa sebagai landasan pelaksanaan hak dan kewajiabn bela negara, hal ini dimaksudkan untuk kelangsungan hidup berbangsa dan bernegara.

Selain itu, Pendidikan Kewarganegaraan pada dasarnya adalah sebuah pendidikan untuk generasi penerus bangsa yang tujuan utamanya agar menjadikan mereka sebagai warga negara yang dapat memiliki pemikiran kritis dan sadar akan hak dan kewajibannya dalam hidup bermasyarakat dan bernegara agar siap menghadapi perkembangan dunia. Melihat tantangan dunia saat ini begitu berat, terlebih dari segi teknologi, Indonesia masih dibilang tertinggal daripada negara-negara lainnya. Jangan sampai masyarakat Indonesia kalah dalam "perang pemikiran" di era globalisasi seperti ini. Masyarakat harus tetap dapat berpegang teguh dan mempertahankan ideologinya, yakni Pancasila.

\section{B. Karakter Berbangsa dan Bernegara Indonesia}

Karakter adalah watak, tabiat, akhlak , atau kepribadian seseorang yang terbentuk dari hasil internalisai berbagai kebajikan yang diyakini dan digunakan sebagai landasan untuk cara pandang, berpikir, bersikap, dan bertibdak. Kebajikan terdiri atas sejumlah nilai, moral, dan norma seperti jujur, nerani bertindak, dapat dipercaya, dan hormat kepada orang lain. Interaksi seseorang dengan orang lain menumbuhkan karakter bangsa (Rahmatiani, 2017).

Terdapat empat pilar yang harus dibela dan dijaga untuk menopang karakter kebangsaan Indoensia, yaitu sebagai berikut :

1) Negara Kesatuan Republik Indonesia

Bagi lebih dari 240 juta jiwa penduduk Indonesia, Negara Kesatuan Republik Indonesia bagaikan rumah tempat tinggal mereka. Secara fisik, Indonesia membentang dari Kota Sabang 
hingga Merauke, dari Miangas hingga Pulau Rote. Berkisar antara 240 juta jiwa, penduduk negara Kesatuan Republik Indonesia terdiri dari berbagai suku yang memiliki adat dan budayanya. Mereka juga memeluk agamanya masingmasing, yang mana di Indonesia diakui terdapat enam agama resmi yakni Islam, Katolik, Protestan, Hindu, Budha, dan Kong Hu Chu). Hal-hal inilah yang menyebabkan NKRI disebut negara majemuk.

2) Pancasila

Pancasila merupakan dasar negara dan falsafah NKRI. Maka dari itu, Pancasila harus dijadikan pedoman, ideologi, dan standar berfikir dalam menjalankan kehidupan berbangsa dan bernegara. Apa yang kita lakukan harus sesuai dengan nilai-nilai yang terkandung dalam Pancasila.

3) Undang-Undang Dasar Negara Republik Indonesia Tahun 1945

Pada hakikatnya, UUD 1945 merupakan aturan utama yang megatur penduduk NKRI dalam menjalankan kehidupannya sebagai warga negara Indonesia. UUD 1945 disahkan pada 18 Agustus 1945 dan telah mengalami perubahan atau amandemen sebanyak empat kali.

4) Bhineka Tunggal Ika

Sebagai semboyan hidup/prinsip hidup, Bhineka Tunggal Ika haruslah dipraktekan dalam kehidupan sehari-hari oleh setiap warga negara NKRI. Bhineka Tunggal Ika memberikan kesadaran kepada kita bahwa perbedaan akan selalu ada, baik itu perbedaan agama, suku bangsa, golongan, atau ras. Namun adanya perbedaan ini jangan menjadikan alasan terjadinya perselisihan, justru kita harus saling menghormati, menghargai dan bertoleransi terhadap perbedaan tersebut.

\section{Tujuan Kewarganegaraan}

Pendidikan

Tujuan utama dari Pendidikan Kewarganegaraan ialah untuk menumbuhkan wawasan dan kesadaran bernegara, sikap serta perilaku yang cinta tanah air dan bersendikan kebudayaan bangsa, wawasan nusantara, serta ketahanan nasional dalam diri para generasi penerus bangsa yang sedang meimba ilmu pengetahuan dan berusaha menguasai teknologi, serta tetap mempertahankan seni. Pendidikan Kewarganegaraan diharapkan dapat menhasilkan warga negara yang sadar akan hak dan kewajibannya sebagai bagain dari Banga Indonesia yang merdeka serta tidak jadi beban bagi siapapun, yang melibatkan diri dalam kegiatan belajar, memahami garis besar sejarah, cita-cita dan tujuan bernegara. Menurut Isep (2013: 15) "fungsi dan tujuan Pendidikan Kewarganegaraan adalah untuk membentuk atau mempersiapkan peserta didik menjadi warga negara yang baik". Sementara warga negara yang baik adalah warga negara yang mengetahui dan memahami hak-hak dan kewajiban-kewajibannya sebagai warga negara. Hak-hak dan kewajibankewajiban warga negara terumuskan dalam berbagai peraturan perundangundangan yang ditetapkan oleh negara. 


\section{Peran}

Pendidikan

\section{Kewarganegaraan}

Materi pada Pendidikan Kewarganegaraan dapat dihubungkan dengan nilai-nilai karakter bangsa. Ada beberapa nilai atau karakter yang dapat menjadi patokan dalam pengembangan karakter generasi penerus, yaitu sebagai berikut.

1. Nilai Religius

Yakni sikap patuh terhadap ajaran agama yang dianutnya, dan tidak meremehkan agama lain. Karakter religius ini diharapkan dapat menjadi landasan nilai, moral, dan etika dalam bertindak

2. Jujur

Yakni perilaku yang didasarkan pada upaya menjadikan dirinya sebagai orang yang dapat dipercaya dalam perkataan, tindakan, dan pekerjaa. Sikap jujur ini diharapkan memperkecil kemungkinan terjadinya kesalahpahaman antar individu, saling menuduh, dan bahkan membenci. Hal ini dapat terjadi karena seseorang telah dibohongi.

3. Tanggung Jawab

Sikap tanggung jawab dapat menunjukkan probadi yang layak untuk mendapat kepercayaan dalam melakukan sesuatu dan dapat menanggung akibat dari hal yang dilakukannya.

4. Toleransi

Yakni sikap dan tindakan menghargai sebuah perbedaan. Sikap toleransi ini diharapkan dapat mempermudah masyarakat untuk saling berbaur, tanpa adanya diskriminasi, baik itu dari segi agama, ras, ataupun budaya.
5. Disiplin

Sikap disiplin yakni menaati setiap peraturan atau tata tertib yang berlaku. Dengan melatih sikap disiplin, ini dapat menunjukkan bagaimana seseorang menghargai dan menjunjung tinggi setiap atiran yang telah disepakati.

6. Kerja Keras

Seseorang yang kerja keras dapat dilihat dari tindakannya yang mandiri, selalu optimis, dan selalu tegas.

7. Kreatif

Seseorang yang cerdas dapat berpikir secara kreatif dan juga kritis. Hal ini memberi peluang besar untuk hal-hal inovatif yang dapat dilakukan oleh seseorag.

8. Demokratis

Sikap demokratis yakni berupa cara berfikir, bersikap, dan bertindak yang mana menilai sama antara hak dan kewajiban dirinya dan orang lain.

9. Semangat Kebangsaan dan Cinta Tanah Air

Tanpa adanya kesadaran serta semangat kebangsaan dan cinta tanah air dari warganya, maka sebuah cita-cita bangsa yang memiliki karakter tidak akan tercpai. Hal ini tentunya karena karakter bangsa muncul dari para warga negaranya.

10. Peduli Lingkungan dan Sosial Sikap peduli lingkungan dan sosial ini merupakan cerminan kepedulian masyarakat terhadao lingkungan yang mana akan menjadikan manusia dan lingkungannya saling mencintai. Baik itu dengan sesama manusia, maupun makhluk hidup lainnya. 
Seperti yang tadi saya bahas bahwa terdapat empat pilar yang menjadi tumpuan untuk mempertahankan karakter bangsa Indonesia, yakni NKRI, Pancasila, UUD 1945, dan Bhineka Tunggal Ika, yang mana hal-hal ini terdapat dalam konten pembelajaran Pendidikan Kewarganegaraan. Maka Pendidikan Kewarganegaraan ini menjadikan generasi penerus bangsa agar memiliki ilmu pengetahuan, pengembangan keahlian, dan tentunya karakter publik. Dengan terus meningkatkan rasa nasionalisme atau kewarganegaraan, maka kita tidak akan mudah goyah dengan hal-hal yang dapat melunturkan rasa cinta tanah air. Kita tidak akan dengan mudah terpengaruh oleh aurs globalisasi yang membawa budaya asing. Sehingga kita dapat tetap mempertahankan karakter-karakter masyarakat Bangsa Indonesia yang tinggi akan nasionalisme dan berbudaya.

Melihat begitu pentingnya peran Pendidikan Kewarganegaraan, maka lembaga pendidikan tidak akan mengabaikan pentingnya karakter bangsa dan media pendidikan kewarganegaraan. Agar tercitpta karakter yang diingikan maka pendidikan perlu berupaya dan berkontribusi untuk memmberi sebuah pengalaman yang dapat menumbuhkan karakter bangsa. Salah satu upayanya yakni tentu melalui pembelajaran. Pada dasarnya kegiatan pembelajaran selain untuk menjadikan generasi penerus menguasai kompetensi, juga dirancan untuk menjadikan peserta didik dapat mengenal, menyadari, serta menginterpretasikan nilainilai dan menjadikannya sikap atau perilaku dalam kehidupan.

\section{SIMPULAN}

Kewarganegaraan dalam bahas latin disebut civis, selanjutnya dari kata civis dalam bahasa Inggris timbul kata civic, artinya mengenai warga negara atau kewarganegaraan. Kemudian dari kata civic muncullah kata civics yang berarti ilmu kewarganegaraan dan civic education yang berarti pendidikan kewarganegaraan.

Pendidikan Kewarganegaraan diharapkan dapat menhasilkan warga negara yang sadar akan hak dan kewajibannya sebagai bagain dari Banga Indonesia yang merdeka serta tidak jadi beban bagi siapapun, yang melibatkan diri dalam kegiatan belajar.

Selain itu, Pendidikan Kewarganegaraan pada dasarnya adalah sebuah pendidikan untuk generasi penerus bangsa yang tujuan utamanya agar menjadikan mereka sebagai warga negara yang dapat memiliki pemikiran kritis dan sadar akan hak dan kewajibannya dalam hidup bermasyarakat dan bernegara agar siap menghadapi perkembangan dunia. Melihat tantangan dunia saat ini begitu berat, terlebih dari segi teknologi, Indonesia masih dibilang tertinggal daripada negaranegara lainnya. Jangan sampai masyarakat Indonesia kalah dalam "perang pemikiran" di era globalisasi seperti ini. Masyarakat harus tetap dapat berpegang teguh dan mempertahankan ideologinya, yakni Pancasila. Oleh karena itu, terdapat empat pilar yang dapat menjadi tumpuan untuk mempertahankan karakter bangsa Indonesia, yakni NKRI, Pancasila, UUD 1945, dan Bhineka Tunggal Ika.

Pendidikan Kewarganegaraan ini menjadikan generasi penerus memiliki ilmu pengetahuan, pengembangan keahlian, dan tentunya karakter publik. Dengan terus 
meningkatkan rasa nasionalisme atau kewarganegaraan, maka kita tidak akan mudah goyah dengan hal-hal yang dapat melunturkan rasa cinta tanah air. Kita tidak akan dengan mudah terpengaruh oleh aurs globalisasi yang membawa budaya asing. Sehingga kita dapat tetap mempertahankan karakter-karakter masyarakat Bangsa Indonesia yang tinggi akan nasionalisme dan berbudaya.

\section{DAFTAR PUSTAKA}

Aminah, S. (2018). Optimalisasi Peran Keluarga dan Sekolah Sebagai Basis Penguatan Pendidikan Karakter. Jurnal PPKn. 6 (1). [Online]. Diakses dari :

http://jurnal.ppkn.org/index.php/j\% $9 \mathrm{kn}$

Ananda, A. (2012). Pendidikan Kewarganegaraan dan Pendidikan Karakter Bangsa. Hal 258-282. [Online]. Diakses dari : http://ejournal.unp.ac.id/index.php $\mathrm{jd} /$ article/view/2558/2163

Dianti, L. (2014). Integrasi Pendidikan Karakter Dalam Pembelajatan Pendidikan Kewaraganegaraan Untuk Mengembangkan Karakter Siswa. Jurnal Pendidikan Ilmu Sosial. 23 (1). [Online]. Diakses dari : https://ejournal.upi.edu/index.php/ pis/article/download/2062/1453

Elisa, N. (2004). Peranan Pendidikan Kewarganegaraan Dalam Pendidikan Karakter Bangsa. [Online]. Hal 17-31. Diakses dari : https://ejurnal.univamedan.ac.id/i dex.php/kalamkeadilan/article/do nload/44/33

Japar, M. dkk. (2019). Peran Pelatihan Penguatan Toleransi Sosial Dalam Pembelajaran Pendidikan Pancasila Dan Kewarganegaraan Di Sekolah Menengah Pertama. Jurnal Pendidikan Ilmu Sosial. 29 (2), hal 94-104. [Online]. Diakses dari : http://journals.ums.ac.id/index.php jpis/article/download/8204/5044

Juliardi, B. (2015). Implementasi Pendidikan Karakter Melalui Pendidikan Kewarganegaraan. Jurnal Bhinneka Tunggal Ika. 2 (2), hal 119-126. [Online]. Diakses dari

https://ejournal.unsri.ac.id/index.p $\mathrm{p} / \mathrm{jbti} /$ article/view/4581

Lestari, G. (2015). Bhinneka Tunggal Ika : Khasanah Multikulutral Indonesia di Tengah Kehidupan Sara. Jurnal Pendidikan Pancasila dan Kewarganegaraan. [Online]. Diakses dari http://journal.um.ac.id/index.php/j pk/article/download/5437/2037

Maftuh, B. (2008). Internalisasi Nilai-Nilai Pancasila dan Nasionalisme Melalui Pendidikan Kewarganegaraan. [Online]. Diakses dari http://file.upi.edu/Direktori/JUR AL/EDUCATIONIST/Vol._II_N 2Juli_2008/7_Bunyamin_Maftu rev.pdf

Muzayanah, M. (2020). Pendidikan Kewarganegaraan Bagi Bahasiswa Upaya Komitmen Cinta Negara Kesatuan Republik Indonesia (NKRI) dan Bela Negara). Jurnal Pendidikan UNDIKSHHA. 8 (1).

[Online]. Diakses dari : https://ejournal.undiksha.ac.id/ind x.php/JJPP/article/view/23606

Nurmalisa, Y. Dkk. (2020). Peranan Pembelajaran Pendidikan Kewarganegaraan Dalam Membangun Civic Consecience. Jurnal Bhinneka Tunggal Ika. 7 (1). [Online]. Diakses dari : https://ejournal.unsri.ac.id/index.p p/jbti/article/download/10082/pdf

Rahmatiani, L. (2020). Pendidikan Kewarganegaraan Sebagai Pembentuk Karakter Bangsa. Dalam Seminar Nasional Kewarganegaraan. [Online]. Diakses dari 
http://seminar.uad.ac.id/index.php snk/article/view/3665/pdf

Wibowo, A. dkk. (2017). Pendidikan Kewarganegaraan : Usaha Untuk Memperkuat Multikulturalisme di Indonesia. Junral Civics. 14 (2). [Online]. Diakses dari : https://journal.uny.ac.id/index.php civics/article/download/16043/pdf

Sari, Y. (2014). Pembinaan Toleransi dan Peduli Sosial Dalam Upaya Memantapkan Watak Kewarganegaraan (Civic Disposition) Siswa. Jurnal Pendidikan Ilmu Sosial. 23 (1). [Online]. Diakses dari https://ejournal.upi.edu/index.php/ pis/article/view/2059

Setianingsih, U. dkk. (2019). Implementasi Nilai-Nilai Bhineka Tunggal Ika pada Siswa Kelas VII SMP Negeri 1 Surakarta pada Tahun Pelajaran 2016/2017. [Online]. Diakses dari : http://journal.univetbantara.ac.id/i dex.php/cessj/article/view/359

Suharyanto, A. (2013). Peranan Pendidikan Kewarganegaraan Dalam Membina Sikap Toleransi Antar Siswa. Jurnal Ilmu Pemerintahan dan Sosial Politik. 1 (2). [Online]. Diakses dari http://ojs.uma.ac.id/index.php/jpp $\mathrm{ma} /$ article/view/563/403 